\title{
Zavadska D. INVESTIGATION OF THE INTERACTION OF FISCAL AND MONETARY POLICIES IN THE CONDITIONS OF ECONOMIC GROWTH IN UKRAINE
}

Проведено оцінку взаємодї грошово-кредитної та бюджетно-податкової політики. Визначено особливості економічного розвитку України. Досліджено чинники формування державного боргу України. Встановлено, що в національній економічі відсутній позитивний синергічний ефект фіскальної та монетарної політики. Викладено результати аналізу боргових зобов'язань держави та грошово-кредитного регулювання. Запропоновано заходи регулятивного впливу держави на ринкову кон'юнктуру.

Ключові слова: монетарна та фіскальна політика, чинники та інструменти ефективної взаємодії, структура та управління борговими зобов'язаннями держави.

\section{Introduction}

In Ukraine, the processes of a long-term systemic financial and economic crisis are engulfing the real sector of the economy, public finances, the monetary sphere, the banking system, and the financial market. Consequences of the crisis are the imbalance of the economy, a drop in the rates of economic growth, a decrease in the level of competitiveness and investment attractiveness of the country. The outflow of financial and human capital abroad, the rapid depreciation of the hryvnia, the decline in trust and the degradation of the role of the banking sector in credit are prompted to find ways to improve the quality of the growth of the national economy.

To ensure financial stability and sustainable economic growth, the conceptual rethinking of the implementation of state financial policy, in particular the interaction of fiscal and monetary, having a different, and in some cases, opposite, impact on economic processes is relevant. The ill-conceived fiscal policy has a negative impact on setting monetary policy objectives, the efficiency of the allocation of financial resources and increases the risks of government debt.

\section{The object of research and its technological audit}

The object of research is the processes of fiscal and monetary regulation, as well as the results of their impact on the economy of Ukraine.

The scale of state borrowing makes them a factor of influence on various sectors of the Ukrainian economy, in particular, the monetary sphere. In order to formulate recommendations for ensuring the effectiveness of the policy of state borrowings and developing measures to prevent possible risks, problems of managing the state's debt obligations, stability of financing the state budget, and stability of the domestic market are investigated [1,2].

Special attention is paid to the problems of transition from passive debt financing of the budget deficit to active influence on the implementation of strategic development guidelines, turns the policy of state borrowing from the fiscal mechanism into a component of macroeconomic policy [3-6].

Acceleration of the rates of socioeconomic development of Ukraine depends largely on the overall economic stability, based on ensuring the effectiveness of the functioning of the mechanism of state economic regulation. With the aim of reforming the economy, the Strategy of Sustainable Development «Ukraine 2020» [7] was adopted. The implementation of the Comprehensive Program for the Development of the Financial Sector of Ukraine until 2020, which is aimed at overcoming crisis phenomena and the formation of monetary prerequisites for economic development, will accelerate the implementation of the financial sector reform [8]. However, let's note that the implementation of the Association Agreement between Ukraine and the European Union, the Memorandum of Cooperation with the International Monetary Fund will not substantially ensure sustainable economic development, development of a market competitive environment in accordance with the standards of the European Union [9]. Therefore, it is necessary to overcome the problems of the development of the domestic market, the achievement of common goals of economic policy by ensuring the interaction of monetary and fiscal policies.

\section{The aim and objectives of research}

The aim of research is development of recommendations for increasing coherence of actions, coordination of fiscal and monetary measures. Solving the goal contributes to the following tasks:

1. To investigate the trends of changes and components of inflation in Ukraine as a factor of state development.

2. To conduct an assessment of the accumulation of Ukraine's public debt, determine the direction of reducing the debt burden on the economy, increasing the efficiency of the use of external and internal borrowing.

3. To determine the interaction of the main variables that characterize Ukraine's fiscal and monetary policies. 


\section{Research of existing solutions of the problem}

Despite the fact that the policy of state borrowings and the effectiveness of its provision are the subject of scientific research by many scientists [10-12], the analysis of recent publications convincingly shows that the issues of ensuring coordination of fiscal and monetary policy in Ukraine remain important.

The issues of stability of Ukraine's public finances, regulation of external public debt, monetary and fiscal levers of influence on investment processes are devoted to a significant number of scientific works of researchers.

So, according to the authors of [13], «state funds unlike other sources (own and bank loans) in recent years have not become an effective lever for activating investment and innovation activities of economic entities ... the direction of effective use of budgetary levers in the investment process should become a conceptually important tool for implementing the state's financial policy in promoting economic growth through the modernization of the state's economy and increase its competitiveness in the open markets».

As the author points out [14], «the management of public debt in foreign countries is carried out on the basis of clear plans, taking into account the impact of macroeconomic indicators, directly depend on the amount of public debt, on the social situation in the state. Given this, the country's rating in the international community is raised, which means that the credibility of creditors and investors is growing, which is necessary to obtain new borrowings with the condition of their targeted use for the development of economic links that contribute to the improvement of macroeconomic indicators related to the change in the volume of public debt».

In accordence with the author's [15] view «the budget deficit is permanently inherent in the public finances of most countries of the world, both develop it and with emerging markets, therefore it is necessary to follow certain rules on the directions of using budget funds received from financing the budget deficit. It is important that the funds that come to the budget due to the increase in public debt or the sale of state assets are directed to innovative investment projects (the creation or acquisition of new assets of collective property, including state assets) or to repay the principal amount of the existing public debt. This is why most of the world's countries introduced budget restrictions in the budget legislation, the so-called «golden rule», according to which the size of the budget deficit can't exceed the amount of budget investments in the relevant budget period. However, despite the existence of a similar norm in the Budget Code of Ukraine, it is not always possible to adhere to its government, especially in recent years».

It is considered that «Modern economic thought, regardless of its specific theoretical direction, recognizes the responsibility of the state for the state of the country's economic development ... for achieving its main objectives, economic policy provides for a wide range of activities ... relating to the market policy implemented through the regulatory influence of the state on the market conjuncture, the ratio of aggregate demand, supply in the market. Therefore, according to the method and nature of the impact on the behavior of economic agents, all activities of this policy are divided into three groups:

1) measures of budgetary-fiscal (fiscal) policy;

2) measures of monetary-credit (monetary) policy;

3) direct impact measures».

According to the source [17] «under certain conditions, the implementation of discretionary policies causes the emergence of equilibrium conditions with low inflation. The struggle of the financial authorities with inflation, relying on a good reputation, affects the expectations of the private sector of future inflation. The cooperation of fiscal and monetary policy must take into account conflicting interests. In this scenario, economic secondary effects are provoked and external factors (externalities) become very important».

In [18] opinion, «in response to the crisis, the retrospective emphasis seems to have been on monetary, rather than budgetary expansion. But the cyclically adjusted budget figures show that the fiscal position was long-lasting (expansionary) before the crisis. The demand management policy was equally supported in the US and the UK in the early stages of the crisis, much more than in the EMU (European Monetary Union)».

The author [19] suggest that «although monetary and fiscal policy is implemented by two different state bodies, they are not independent. Changes in one of the bodies will affect the effectiveness of the work of the other and, thus, will have a general effect on changes in any policy. Tensions can arise between how each of the policies will help smooth the economic cycles, achieve macroeconomic stability and growth. That is why it is important to monitor the combination of monetary and fiscal policies, and coordinate their actions (and other policies) more carefully to avoid tension or inconsistency. This combination of policies is a key component of the IMF's macroeconomic policy recommendations and IMF-supported economic adjustment programs, together with external, structural and sectoral policies. In practice, it has been proved that the imbalance in the fiscal position in many cases is a key element of both macroeconomic problems and the ways to solve them».

It is represented that «at the beginning of the activity of the European Monetary Union (EBU), macroeconomic theory has been adapted in the literature to analyze various issues on policy development in the international framework ... One of the most pressing issues is the study of the interaction between centralized monetary policy and many decentralized fiscal policies. ... The global financial crisis, the macroeconomic imbalance of the European Monetary Union and the sovereign debt crisis in some member countries have raised issues related to the target indicators There are the Central Bank (European Central Bank), the degree of the policy of coordination of the EBU, compliance with the rules of taxation and the obligations of politicians to perform their assigned tasks. This led to a revival of interest in theoretical literature, which explores the issues of interaction of monetary and fiscal policy in the EMU. The theory provides answers to these questions and allows us to evaluate the current process of viewing the institutional structure as the basis for a combination of EBU policies» [20].

In author [21], the nonlinearities caused by the restriction of interest rates demonstrate strong where-inflationary effects in response to a reduction in budget expenditures ... rather than their increase. 
It is reported that the inability of central banks to raise inflation expectations at zero bottom threshold, the lack of coordination between monetary authorities and fiscal authorities ... interact inappropriately to achieve the desired level of inflation [22].

\section{Methods of research}

To solve the problems, the following methods are used: systematic, theoretical generalization, analysis, comparative comparison, graphical presentation of the research results.

\section{Research results}

The main goal of monetary policy is regulation of the stability of the monetary unit of Ukraine, to contain inflation, to stabilize the price level of employment and to stimulate economic growth by controlling interest rates and offering money. At the same time, in modern conditions, these tasks are impossible without ensuring proper coordination with fiscal policy.

One of the most acute problems of fiscal policy is the financial replenishment of the budget of Ukraine and cost optimization. The distribution of budgetary appropriations should be carried out taking into account the influence of factors of the political and economic environment, in particular effective demand of the population and the level of economic culture of enterprises in the real sector.

The analysis of coordination of monetary and fiscal policy in the national economy testifies to the lack of a positive synergetic effect, primarily due to the unsuccessful attempts of the National Bank of Ukraine to apply inflation targeting.

According to the monetary policy strategy for 2016-2020: the implementation of the inflation targeting regime, target inflation targets are planned as $12 \% \pm 3 \%, 8 \% \pm 2 \%$, $6 \% \pm 2 \%, 5 \% \pm 1 \%, 5 \% \pm 1 \%$, for $2016-2020$ respectively. However, the level of inflation does not correspond to the target value from the second half of 2017 [23]. Dispersion of the values of individual components of the consumer price index indicates the instability of compliance with the target level and the sensitivity to the order of calculation of the indicator. For example, households, which significant part of income is used to pay utility bills, in 2016 are more sensitive to the component «Housing, utilities». In addition, a significant excess of the producer price index value of the consumer price index, indicates the possibility of manipulating the level of inflation due to the components of the consumer basket (Fig. 1, 2).

The non-monetary nature of inflation in Ukraine requires a systemic approach based on combining monetary and fiscal policy tools that will help reduce economic imbalances and address the strategic challenges of state development.

To provide the National Bank of Ukraine with an acceptable level of the consumer price index, government support is needed to effectively use the fiscal policy tools (investments, tax incentives, etc.).

Minimization of the critical impact of the financial sector on the socio-economic development of the country is largely achieved through a balanced monetary and debt policy, the important components of which are forecasting, analysis, evaluation and effective management of debt risks. The key task of the country's debt policy is keeping the debt load at a safe level. Ensuring the sustainability of the financial system requires research into the negative impact of the formation of public debt, in particular the hryvnia devaluation, the drop in real GDP, changes in the real interest rate of the National Bank of Ukraine, and the growth of the state budget deficit.

The critical state of Ukraine's public debt is evidenced on the existence of serious problems of the financial system during 2014-2017 (Fig. 3).

Starting from 2010, the public debt tends to grow, caused by the global crisis of 2008-2009. And further deterioration of the socio-economic situation in Ukraine. Steady tendency of growth of the public debt in 2016-2017. It is characterized by an increase in the government's expenses for servicing its own debt obligations, a reduction in the currency offer and devaluation of the hryvnia. State and government-guaranteed debt of Ukraine in September 2017 amounted to $82 \%$ of GDP, which accounts for $5 \%$ of GDP.

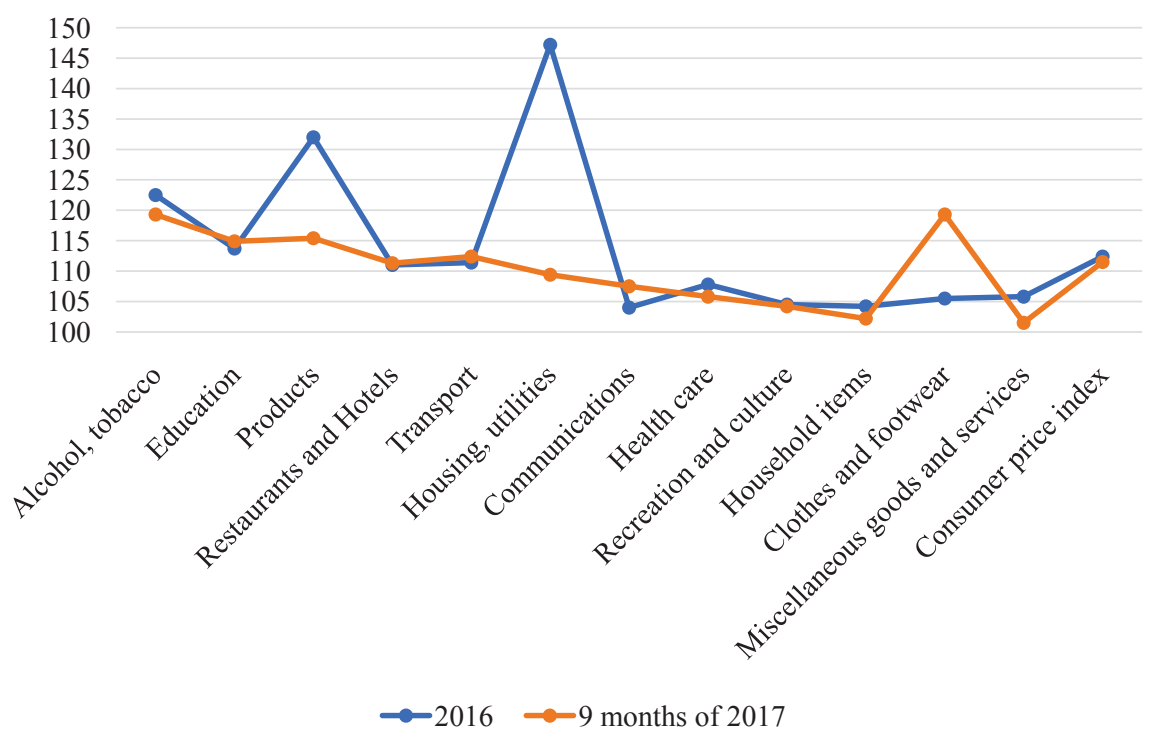

Fig. 1. Components of the consumer price index for the period $2016-9$ months of $2017, \%[24,25]$ 


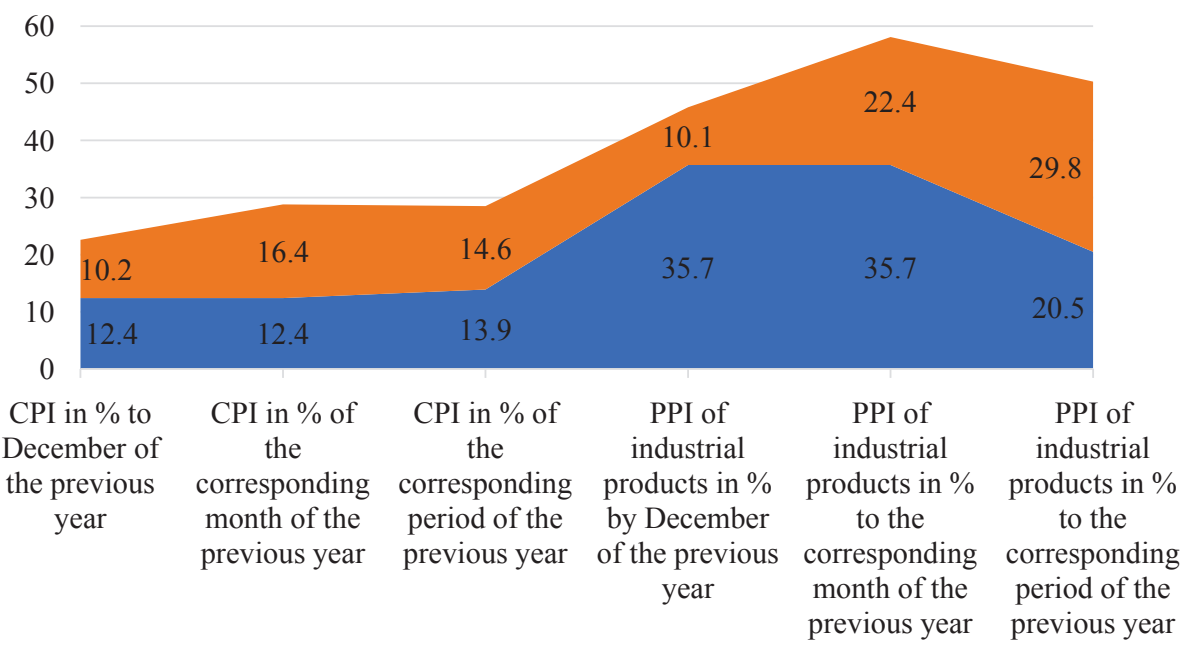

ロ $2016 \square 2017$

Fig. 2. Actual values of the consumer price index and the producer price index of industrial products in 2016-2020, \% [26, 27]

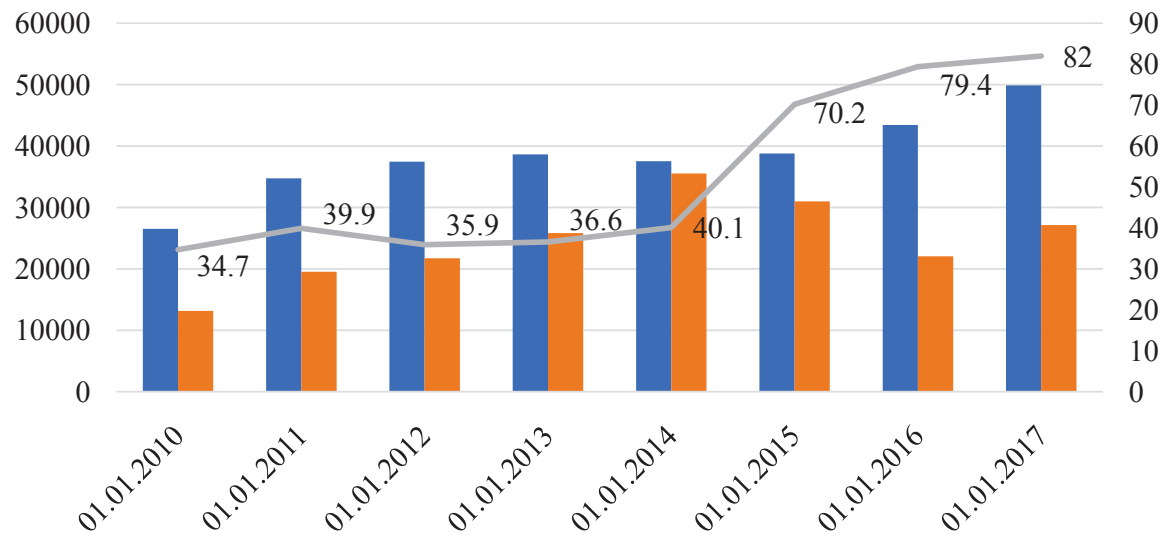

External debt, Billion UAH $=$ Internal debt, Billion UAH $—$ In $\%$ of GDP

Fig. 3. Dynamics and structure of Ukraine's public debt for the period 2010 - 9 months of 2017 [28]

Given the limited opportunities for capital raising by the private sector, the financing for the growing deficit in the current account of the balance of payments is provided mainly through government debt obligations and monetary regulation. Over the period 2014 - 9 months of 2017 Ukraine increased the level of state and state guaranteed debt by a factor of 3.34 (from 584.1 billion to 1.95 trillion UAH). This is due to additional capitalization by the government of state-owned banks (PJSC Oschadbank, PJSC Ukreximbank, PJSC PrivatBank and Individual Deposits Guarantee Fund) through domestic borrowings through issuance of Government Bonds in the amount of 15.27 billion UAH.

During 2012 - 10 months of 2017, the largest share is borrowed through the placement of government bonds, the share of which fluctuates, but does not fall below the level of $50 \%$. It should be noted that in the structure of the external debt in the context of creditors, the largest share is accounted for by:

- The International Monetary Fund (for the period 2014 - 8 months of 2017, the size of loans cut off from 3.65 to 5.22 billion USD and is $35.4 \%$ );
- International Bank for Reconstruction and Development (at the end of the period the volume of loans is 4.90 billion USD or $33.58 \%$ );

- Russia, which share of loans is gradually replaced by means of other creditors (growth rate for 2012-2016 is $76.25 \%$ ) (Table 1$)$.

Let's note that the threshold is considered to be a level of debt that allows the state, without the assistance of international financial organizations or other entities, to timely and fully fulfill their debt obligations. The implementation of government borrowing in the capital markets at acceptable interest rates does not require the implementation of measures to restructure debt obligations and declare a default.

The indicator of the general level of the debt burden, which is determined by the Budget Code of Ukraine in the amount of not more than $60 \%$ of GDP, from 2014 is more critical and has a steady upward trend (from $65.4 \%$ in 2014 to $82.0 \%$ in October 2017, or by a factor of 1.25 ). The indicator of the ratio of external debt to the annual volume of exports of goods and services for the period from 2014-2016 increased 2.88 times and amounted to 2016 , or $171.34 \%$, with a recommended value of $200 \%$. 
Dynamics and structure of Ukraine's external debt for the period 2012 - 10 months of 2017, billion dollars*

\begin{tabular}{|c|c|c|c|c|c|c|c|c|}
\hline \multirow{2}{*}{ Components of external debt } & \multicolumn{6}{|c|}{ As of 31.12: } & \multicolumn{2}{|c|}{ Changes for the period, \%: } \\
\hline & 2012 & 2013 & 2014 & 2015 & 2016 & $2017^{* *}$ & $2012-2017^{* *}$ & 10 month of 2017 \\
\hline External debt & 26.14 & 37.93 & 30.82 & 34.43 & 36.05 & 38.52 & 165.38 & 106.66 \\
\hline Debt on loans received from international financial organizations & 10.02 & 7.74 & 10.72 & 14.06 & 13.68 & 14.59 & 145.60 & 106.65 \\
\hline$\%$ of total & 38.33 & 27.71 & 34.78 & 40.84 & 37.95 & 37.87 & 98.81 & 99.78 \\
\hline European Community & 0.00 & 0.00 & 1.66 & 2.41 & 2.31 & 3.26 & $\mathrm{x}$ & 141.12 \\
\hline$\%$ of total & 0.00 & 0.00 & 15.49 & 17.14 & 16.89 & 9.17 & $\mathrm{x}$ & 54.29 \\
\hline European Bank for Reconstruction and Development & 0.53 & 0.60 & 0.59 & 0.58 & 0.59 & 0.64 & 120.75 & 108.47 \\
\hline$\%$ of total & 5.29 & 7.75 & 5.50 & 4.13 & 4.31 & 1.66 & 31.37 & 38 \\
\hline European Investment Bank & 0.40 & 0.54 & 0.49 & 0.52 & 0.53 & 0.60 & 150.00 & 113.20 \\
\hline$\%$ of total & 3.99 & 6.98 & 4.57 & 3.70 & 3.87 & 1.55 & 38.84 & 40.05 \\
\hline International Bank for Reconstruction and Development & 3.03 & 3.07 & 4.33 & 5.20 & 5.06 & 4.90 & 161.71 & 96.83 \\
\hline$\%$ of total & 30.24 & 39.66 & 40.39 & 36.98 & 36.99 & 33.58 & 111.04 & 90.78 \\
\hline International Monetary Fund & 6.05 & 3.54 & 3.65 & 5.34 & 5.18 & 5.19 & 85.78 & 100.19 \\
\hline$\%$ of tatal & 60.38 & 45.74 & 34.05 & 37.98 & 38.87 & 13.47 & 22.30 & 34.65 \\
\hline Debt on loans received from foreign governments & 1.14 & 0.91 & 1.04 & 1.36 & 1.68 & 0.10 & 8.77 & 5.95 \\
\hline$\%$ of total & 4.36 & 2.39 & 3.37 & 3.95 & 5.08 & 0.25 & 5.73 & 4.92 \\
\hline Canada & 0.00 & 0.00 & 0.17 & 0.29 & 0.30 & 0.10 & $\mathrm{x}$ & 33.33 \\
\hline$\%$ of total & 0.00 & 0.00 & 16.34 & 21.32 & 17.85 & 100 & $\mathrm{x}$ & 560.22 \\
\hline Russia & 0.80 & 0.70 & 0.61 & 0.61 & 0.61 & 0.00 & $\mathrm{x}$ & $x$ \\
\hline$\%$ of total & 70.17 & 76.92 & 58.65 & 44.85 & 36.31 & 0.00 & $\mathrm{x}$ & $\mathrm{x}$ \\
\hline Japan & 0.23 & 0.18 & 0.24 & 0.23 & 0.55 & 0.00 & $\mathrm{x}$ & $\mathrm{x}$ \\
\hline$\%$ of total & 20.17 & 19.78 & 23.07 & 16.91 & 32.73 & 0.00 & $x$ & $x$ \\
\hline Germany & 0.06 & 0.01 & 0.01 & 0.23 & 0.22 & 0.00 & $x$ & $x$ \\
\hline$\%$ of total & 5.26 & 1.09 & 0.96 & 16.91 & 13.09 & 0.00 & $\mathrm{x}$ & $\mathrm{x}$ \\
\hline Debt on issued securities in the foreign market & 13.09 & 17.38 & 17.28 & 50.25 & 19.04 & 0.00 & $\mathrm{x}$ & $\mathrm{x}$ \\
\hline$\%$ of total & 50.08 & 62.23 & 56.07 & 19.04 & 52.82 & 0.00 & $\mathrm{x}$ & $\mathrm{x}$ \\
\hline Indebtedness not elsewhere classified & 1.89 & 6.80 & 1.78 & 4.94 & 1.65 & 0.11 & 5.82 & 6.66 \\
\hline$\%$ of total & 7.23 & 1.78 & 5.78 & 1.65 & 4.58 & 0.28 & 3.87 & 6.11 \\
\hline
\end{tabular}

Note: ${ }^{*}$ - composed by the author on the basis of data from [29]; ${ }^{* *}$ - as of October 31, 2017.

The ratio of payments for servicing the external debt to the annual export of goods and services, which value should not exceed $25 \%$, in 2016 is $37.33 \%$, which is compared with 2014. It tended to increase by 3.45 times (Fig. 4).

In accordance with the criteria defined above, Ukraine refers to countries with a significant burden of external debts, which tend to deteriorate. The policy of public debt management requires the development and application of tools for using domestic sources and reserves specific to lowand middle-income countries. The replacement of foreign currency borrowings by domestic, denominated in UAH, will reduce the dependence of Ukraine's public finances on the overflow of international capital and exchange rate fluctuations, and the development and deepening of the domestic capital market will ensure the liquidity of debt instruments.

The servicing of the public debt is carried out by the National Bank of Ukraine's operations in the placement and redemption of government bonds, their repayment and payment of interest. The dynamics of the share of government securities in the assets of the National Bank of Ukraine and Ukrainian banks is shown in Fig. 5, 6 according to which there are processes of increasing quasifiscal operations. This leads to quasi-monetization, distortion of the values of economic indicators, the predicted level and effectiveness of monetary instruments of inflation targeting. Investments of banks in securities, which are refinanced by the National Bank of Ukraine, for the period 2014-2016 increase 1.31 times and make $768.8 \%$ of the investment portfolio and $20.33 \%$ of the net assets of the sector as of the beginning of 2017 (growth rate $320.66 \%)$. This indicates the use of the resources of the banking system to lend to the government.

The channel of bank crediting is a source of financing of investment activity of subjects of economic activities. The National Bank of Ukraine, using the tools of monetary policy, affects the cost and volumes of attracting and placing funds by banks. Effectiveness of lending to the real sector of the economy in 2016-2017 complicated by the reduction in the loan portfolio of banks with a simultaneous increase in the portfolio of government bonds, a significant proportion of banks with foreign capital in the banking system of Ukraine (about $30 \%$ ) and imperfection of the NBU refinancing system. A significant concentration of refinancing resources in the largest and state banks, insufficient control over the use of the resources received, stimulates the implementation of speculative operations and the withdrawal of funds abroad, causes systemic risks of the banking sector of the economy. 


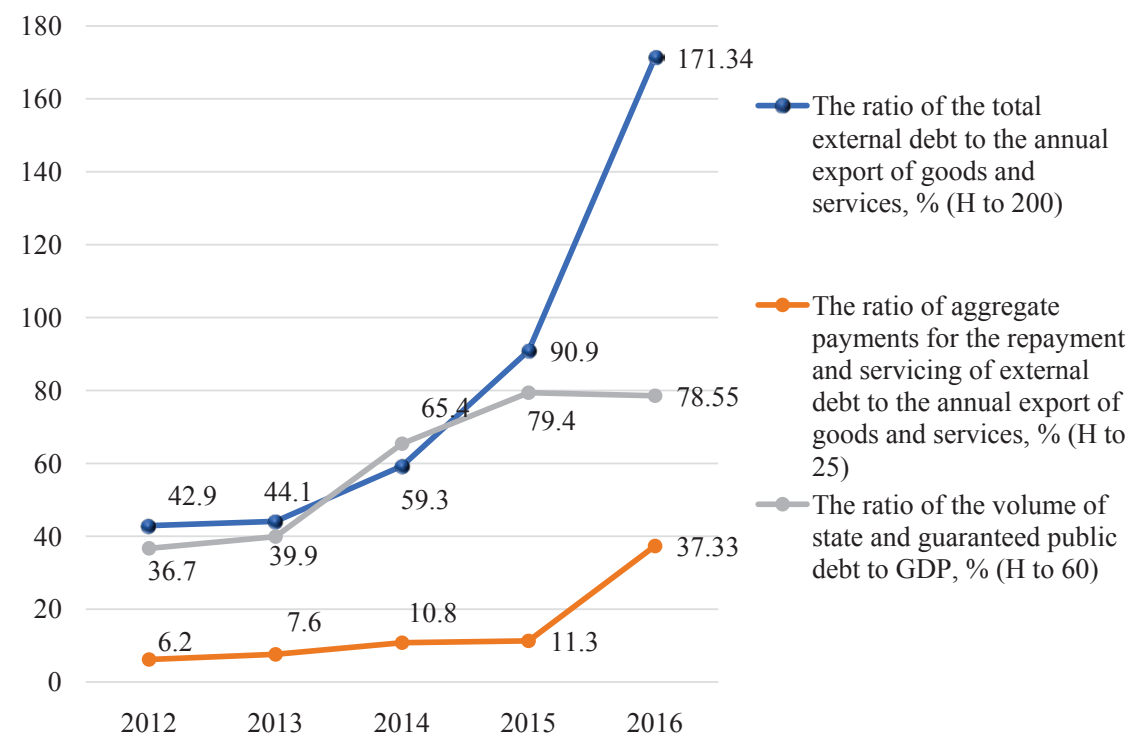

Fig. 4. Dynamics of the criteria for assessing Ukraine's debt burden in 2014-2016 years [30, 31]

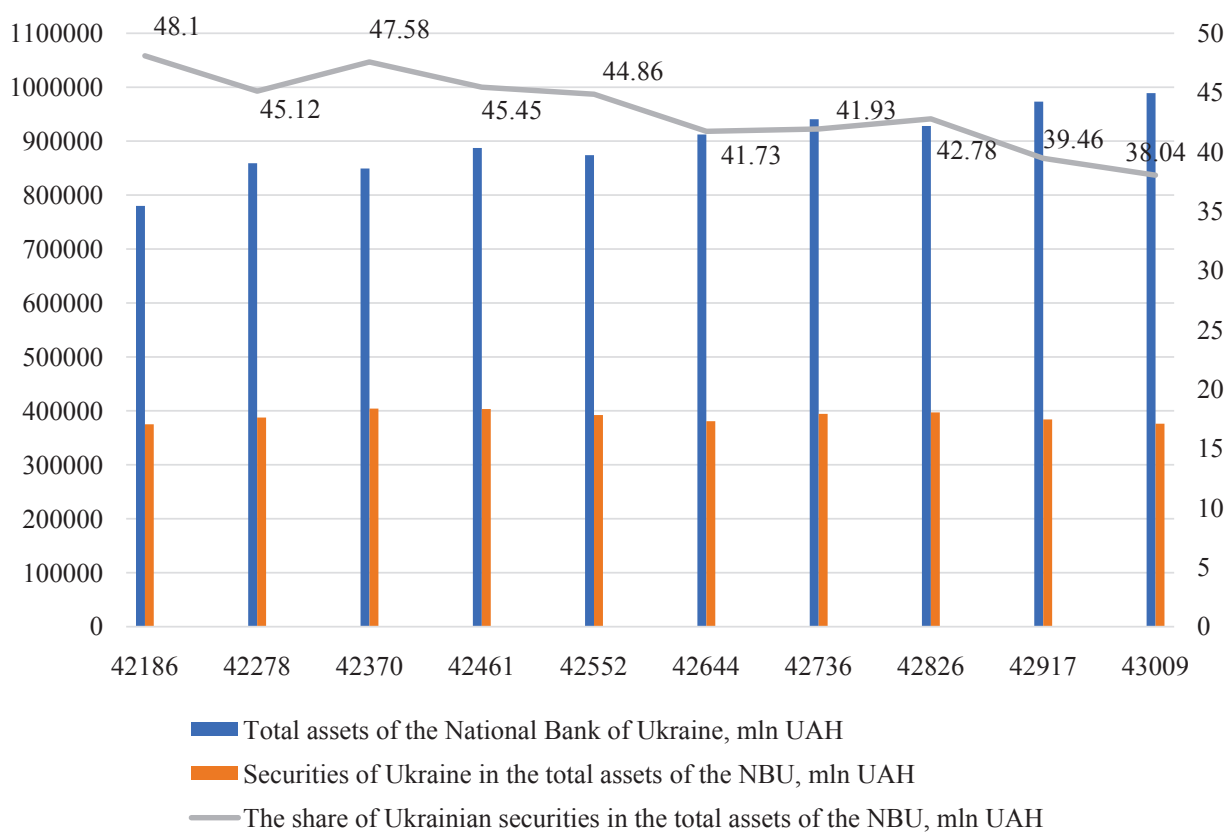

Fig. 5. Dynamics of the share of Ukrainian securities in the total assets of the National Bank of Ukraine for the period 01.07.2015-01.10.2017 [32]

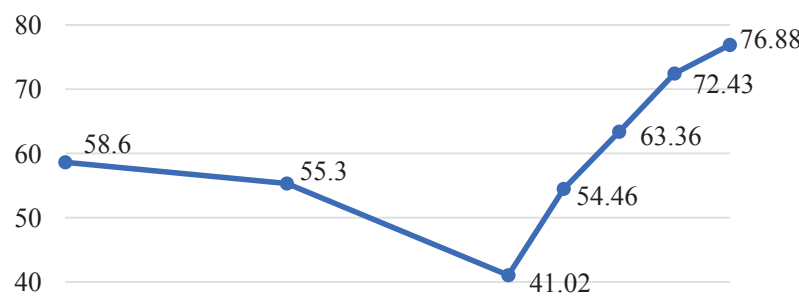

30
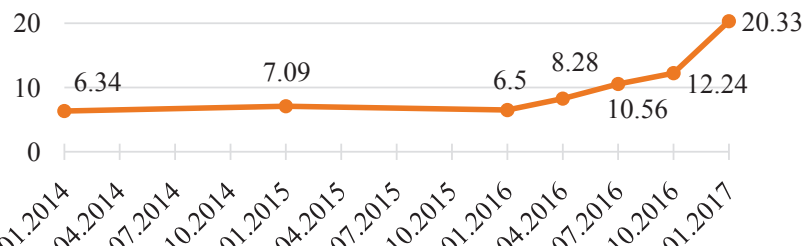
The global financial and economic crisis of 2008-2009 contributed to the revision of the use of the concepts of monetary regulation. Monetary instruments have shown insufficient efficiency, therefore, most modern research focuses on the application of fiscal methods, in particular the Keynesian fiscal multiplier, as a tool for the interaction of monetary and fiscal policies.

In Ukraine, there is a negative relationship between the budget deficit and the size of the real interest rate. The impact of economic instability on the financial market is determined by the high level of inflation and low real interest rates of the National Bank of Ukraine. In the period of stable economic development (1996-2008), the low real interest rate of the NBU is accompanied by GDP growth. For the crisis periods (2008-2009, 2013-2014) low real interest rates of the NBU, high inflation and negative GDP dynamics are typical. This indicates a significant difference in the development of the Ukrainian economy from the economies of developed countries, where high rates of economic growth are accompanied by a relative increase in inflation.

In accordance with the aforementioned, modern inflation in Ukraine has signs of rising cost inflation, which can't be overcome by classical methods of demand reduction [34]. On the contrary, the deteriorating solvency of the population due to the significant devaluation of the national currency, the loss of a portion of deposit investments, the growth of expenditures on currency loans and utility payments have led to a decrease in aggregate demand in the domestic market and requires the development of [35-37]:

- measures aimed at overcoming stagflation, reducing the level of inflation, creating miniature prerequisites for structural reorganization of the national economy, stimulating investment activity in priority sectors of the economy, creating new jobs;

- a doctrine aimed at a clear regulation of the interaction of monetary and fiscal and fiscal on an ongoing basis, taking into account the features of the functioning of the management bodies (the National Bank of Ukraine and the government), relevant to the formation and implementation of tools.

\section{SWOT analysis of research results}

Strengths. The strength of research is that, based on theoretical and empirical generalizations, data are given that provide an opportunity to determine the impact of fiscal policy on the state of the monetary and credit sphere in Ukraine, to determine the direction of implementation of tools. The coordinated interaction of these instruments will contribute to the development of the real sector of the economy.

Weaknesses. The weak side is that the recommended measures to increase the efficiency of combining fiscal and monetary policy instruments in Ukraine can be implemented only in conditions of sustainable economic development and development of a competitive environment in accordance with the standards of the European Union.

Opportunities. Opportunities for further research are the study of the experience of the world's leading countries in shaping the system of public financial management, creating conditions for sustainable economic growth of the state, ensuring macroeconomic stability, the effectiveness of public investment and the implementation of reforms in other areas.

Threats. Threats to the research results are that the provision of financial and macroeconomic stability in Ukraine is due to a significant segmentation of the economic and financial system. Changing the mechanisms for ensuring stability requires prompt response, the development of an adequate system of indicators to assess the impact of new global economic factors.

\section{Conclusions}

1. It has been proved that the measures of fiscal policy, which main goals are to smooth out fluctuations in economic goals, stabilize the rates of economic growth, achieve high employment and moderate inflation, include: - ensuring the economic activation of the stimulating role of fiscal policy:

a) creation of favorable conditions for development of small and medium-sized businesses, the use of a simplified taxation system (taking into account the projected inflation rate) for enterprises that produce innovative products, use innovative technologies, provide services in the field of innovation;

b) optimization of the structure of budget expenditures by outstripping growth of productive costs (for science, infrastructure, health care, education), reduction of unproductive expenditures (financing of executive bodies, etc.);

- stimulation of economic growth on the part of demand: application of a differentiated approach to taxation of the profits of individuals, including low-paid categories of the population, which will contribute to increasing social security and solvent demand of the population, activating the consumer credit market;

- increasing the efficiency of using external borrowed funds aimed at reducing the debt burden on the Ukrainian economy, ensuring the growth of production of goods and services based on innovation:

a) financing of growing sectors of the economy;

b) renovation of the production base of enterprises;

c) introduction of new technologies;

d) transformation of external debt into investments, which will attract additional financial resources to the economy and save gold and foreign exchange reserves.

2. It is shown that the main objective of monetary measures is the implementation of a system of measures in the spheres of monetary circulation and credit aimed at regulating economic growth, stimulating inflation, providing employment and equalizing the balance of payments. To the main monetary instruments that contribute to ensuring the central bank's monetary policy in Ukraine, let's refer:

- stimulating demand for money: improving the lending mechanisms for government programs (lending to prospective activities regardless of ownership, developing incentive framework conditions for investment in large high-tech backbone clusters);

- development of the market for government debt securities: reducing the credit risks of retail investors, ensuring a guarantee of return on investment in bonded loans, developing a system for guaranteeing repayment of investments in government bonds on the stock market for individuals; 
- issue of a mobilization domestic currency loan for the population in the amounts necessary to consistently cover payments on external debt, with a guarantee for liquid state property;

- regulation of import and export of goods: creation of conditions for the repayment of public debt by export commodity deliveries, which will contribute to the growth of exports and the development of domestic competitive production.

3. It is determined that the main prerequisite for Ukraine's stable economic development is ensuring the lack of a budget that can be achieved by expanding and increasing the sources of financing or reducing the state's expenses.

Proceeding from the above, it is advisable to establish a Debt Coordination Council aimed at operational management of the debt of all sectors of the economy, in particular the state. The main tasks for implementation of which involves representatives of the Cabinet of Ministers of Ukraine and the National Bank of Ukraine are:

- coordination with the legislative and executive authorities of methods and tools for debt management, prospectuses for future borrowings;

- estimation and forecasting of currency and interest risks;

- conducting debt management operations;

- participation in the development of debt programs for the future;

- monitoring the financial condition of borrowers;

- development of a set of measures to prevent arrears;

- formation of an optimal portfolio of debt obligations taking into account the world market situation in the international loan capital market, and the like.

\section{References}

1. Havrysh, O. Mekhanizmy vzaiemodii fiskalnoi ta monetarnoi polityky derzhavy [Text] / O. Havrysh, R. Yakymenko //Suchasni problemy ekonomiky ta pidpryiemnytstvo. - 2013. No. 12. - P. 6-10.

2. Yaniv, L. Problemy defitsytu derzhavnoho biudzhetu Ukrainy i shliakhy yikh rozviazannia [Text] / L. Yaniv, O. Zinchenko // Visnyk Dnipropetrovskoho universytetu. Seriia: Menedzhment innovatsii. - 2016. - Vol. 24, No. 6. - P. 144-153.

3. Kryvenko, L. V. Hroshovo-kredytni zasoby rehuliuvannia ekonomiky [Text]: Monograph / L. V. Kryvenko, O. M. Dutchenko, M. I. Syniuchenko et al.; ed. by L. V. Kryvenko. - Sumy: DVNZ «UABS NBU», 2010. - 210 p.

4. Stvorennia fiskalnoho prostoru dlia ekonomichnoho zrostannia. Ohliad derzhavnykh finansiv Ukrainy [Electronic resource] // Dokument Svitovoho banku. Zvit No. 36671-UA. September 14, 2006. - Available at: \www/URL: http:/ documents.worldbank.org/curated/en/996961468308653183/ pdf/366710UKRAINIANOUA0PFR.pdf

5. Unkovskaya, T. Vozrozhdenie ekonomiki Ukrainy: promedlenie opasno [Electronic resource] / T. Unkovskaya // ZN,UA. April 25, 2014. - Available at: \www/URL: https://zn.ua/ macrolevel/vozrozhdenie-ekonomiki-ukrainy-promedlenieopasno- .html

6. Furmanets, K. Formuvannia zovnishnoho derzhavnoho borhu Ukrainy ta finansovyi mekhanizm yoho rehuliuvannia v umovakh hlobalizatsii [Text] / K. Furmanets // Visnyk Vinnytskoho politekhnichnoho instytutu. - 2013. - No. 1. - P. 49-55. Available at: \www/URL: http://ir.lib.vntu.edu.ua/bitstream/ handle $/ 123456789 / 6762 / 1122$.pdf?sequence $=3$

7. Pro Stratehiiu staloho rozvytku «Ukraina-2020» [Electronic resource]: Ukaz Prezydenta Ukrainy No. 5/2015. - January 12, 2015. - Available at: \www/URL: http://zakon2.rada.gov.ua/ laws/show/5/2015
8. Kompleksna prohrama rozvytku finansovoho sektoru Ukrainy do 2020 roku [Electronic resource] // Natsionalna komisiia, shcho zdiisniuie derzhavne rehuliuvannia u sferi rynkiv finansovykh posluh. - February 7, 2017. - Available at: \www/URL: https:// nfp.gov.ua/files/DepFinMon/КПРФСУ 07.02.17.rtf

9. Uhoda pro asotsiatsiiu mizh Ukrainoiu ta Yevropeiskym soiuzom [Electronic resource] // Uriadovyi portal. Yedynyi vebportal orhaniv vykonavchoi vlady Ukrainy. - September 1 , 2017. - Available at: \www/URL: https://www.kmu.gov.ua/ ua/yevropejska-integraciya/ugoda-pro-asociacyu

10. Jarocinski, M. Monetary-fiscal interactions and the euro area's malaise [Electronic resource] / M. Jarocinski, B. Mackowiak // ECB Working Paper No. 2072. - 2017. - 45 p. - Available at: \www/URL: https://publications.europa.eu/en/publicationdetail/-/publication/93990cb4-562c-11e7-a5ca-01aa75ed71a1/ language-en/format-PDF/source-search

11. Mozhlyvosti adaptatsii mizhnarodnoho dosvidu upravlinnia derzhavnym borhom v Ukraini [Electronic resource]. - Available at: \www/URL: http://www.niss.gov.ua/content/articles/ files/upravl_borg-e3b9d.pdf

12. Yurii, S. Faktory vplyvu na derzhavnyi borh [Text] / S. Yurii // Ekonomika i suspilstvo. - 2017. - No. 10. - P. 705-709. Available at: \www/URL: http://www.economyandsociety.in.ua/ journal/10 ukr/120.pdf

13. Maiorova, $\overline{\mathrm{T}}$. Biudzhetni vazheli vplyvu na investytsiinyi protses v Ukraini ta napriamy pidvyshchennia yikh efektyvnosti [Text] T. Maiorova, V. Kuzmenko, C. Urvantseva // Nauchnie trudi SWorld. - 2015. - Vol. 9, No. 4 (41). - P. 36-45.

14. Bosenko, O. Upravlinnia derzhavnymy borhovymy zoboviazanniamy v zarubizhnykh krainakh [Text] / O. Bosenko // Derzhavni finansy. Naukovi pratsi NDFI. - 2016. - No. 2 (75). P. 26-38.

15. Koliada, T. Dzherela finansuvannia defitsytu biudzhetu: tendentsii u zastosuvanni ta vyklyky dlia stabilnosti derzhavnykh finansiv Ukrainy [Text] / T. Koliada // BUZNESINFORM. 2015 - No. 2 - P 215-222 - Available at: \www/URL: http://business-inform.net/pdf/2015/2_0/215_222.pdf

16. Rudenko, M. Kombinuvannia instrumentiv fiskalnoi ta monetarnoi polityky [Text] / M. Rudenko, M. Hlushchenko // Visnyk KDPU imeni Mykhaila Ostrohradskoho. - 2008. No. 1 (48), Part 1. - P. 157-162.

17. Saulo, H. Fiscal and monetary policy interactions: a game theory approach [Text] / H. Saulo, L. C. Rego, J. A. Divino Annals of Operations Research. - 2013. - Vol. 206, No. 1. P. 341-366. doi:10.1007/s10479-013-1379-3

18. Alcidi, C. The interaction between fiscal and monetary policy before and after the financial crisis. Funded by the Horizon 2020 Framework Programme of the European Union Project ID 649261 [Electronic resource] / C. Alcidi, G. Thirion. July 7, 2017. - Available at: \www/URL: http://www.firstrun.eu/ files/2016/07/D4.2_Policy_mix_final_ed.pdf

19. Hilbers, P. Interaction of Monetary and Fiscal Policies: Why Central Bankers Worry about Government Budgets [Electronic resource] / P. Hilbers. - Washington, August 31, 2005. Available at: \www/URL: https://www.imf.org/external/np/ leg/sem/2004/cdmfl/eng/hilber.pdf

20. Foresti, P. Fiscal indiscipline and monetary policy in EMU: Is there any need for a fiscal policy concerned ECB? [Text] P. Foresti, U. Marani // International Journal of Monetary Economics and Finance. - 2013. - Vol. 6, No. 1. - P. 81. doi:10.1504/ijmef.2013.055726

21. Bletzinger, T. The impact of constrained monetary policy on the fiscal multipliers on output and inflation [Text] / T. Bletzinger, M. Lalik // ECB Working Paper No. 2019. - February 20, 2017. 46 p. - Available at: \www/URL: https://publications.europa.eu/ en/publication-detail/-/publication/07319f25-f80b-11e6-8a3501aa75ed71a1/language-en/format-PDF/source-53541364

22. Bianchi, F. The Dire Effects of the Lack of Monetary and Fiscal Coordination [Electronic resource] / F. Bianchi, L. Melosi. - 2017. - Available at: \www/URL: https://economics. indiana.edu/home/about-us/events/conferences-and-workshops/ files/2017-03-02-01.pdf

23. Nikolaichuk, S. Monetarna polityka NBU za rezhymu infliatsiinoho tarhetuvannia: tsili ta faktory pryiniattia rishen [Electronic resource] / S. Nikolaichuk. - Kyiv: Natsionalnyi bank Ukrainy, 2016. - Available at: \www/URL: https://bank.gov.ua/ doccatalog/document?id=38218384 
24. Indeks potrebitel'skikh tsen po vsem kategoriyam v $2016 \mathrm{~g}$. [Electronic resource] // Minfin. Indeksy. - Available at: \www/ URL: https://index.minfin.com.ua/economy/index/inflation/2016

25. Indeks potrebitel'skikh tsen po vsem kategoriyam v $2017 \mathrm{~g}$ [Electronic resource] // Minfin. Indeksy. - Available at: \www/ URL: https://index.minfin.com.ua/economy/index/inflation/

26. Indeksy spozhyvchykh tsin (indeksy infliatsii). Ekonomichna statystyka/Tsiny [Electronic resource] // Derzhavna sluzhba statystyky Ukrainy. - Available at: \www/URL: http://www. ukrstat.gov.ua/operativ/menu/menu u/cit.htm

27. Indeks promyshlennogo proizvodstva [Electronic resource] // Minfin. Indeksy. - Available at: \www/URL: https://index. minfin.com.ua/economy/index/industrial/

28. Dinamika vneshnego gosudarstvennogo dolga i valovogo vneshnego dolga Ukrainy s 2010 po 2017 gody [Electronic resource] // Minfin. Indeksy. - Available at: \www/URL: https://index. minfin.com.ua/index/debt/gov/

29. Derzhavnyi borh ta harantovanyi derzhavoiu borh [Electronic resource] // Ministerstvo Finansiv Ukrainy. - Available at: \www/URL: https://www.minfin.gov.ua/news/borg/derzhavnyiborh-ta-harantovanyi-derzhavoiu-borh

30. Chui, I. Metodychni pidkhody do otsiniuvannia borhovoi bezpeky derzhavy [Text] / I. Chui, O. Mytsak // NLTU Ukrainy. 2016. - No. 26.6. - P. 225-231. - Available at: \www/URL: http://nltu.edu.ua/nv/Archive/2016/26_6/36.pdf

31. Ukraina - kreditnyy reyting [Electronic resource] // Trading Economics. - Available at: \www/URL: https://ru.tradingeconomics. com/ukraine/rating

32. Zvit pro finansovyi stan [Electronic resource] // Natsionalnyi bank. - Available at: \www/URL: https://bank.gov.ua/control/ uk/publish/category?cat_id=27325593

33. Analitychnyi ohliad bankivskoi systemy ukrainy za rezultatamy 2016 roku [Electronic resource] // Natsionalne reitynhove ahentstvo «Riurik». - Available at: \www/URL: http://rurik. com.ua/documents/research/bank_system_4_kv_2016.pdf

34. Arzhevitin, S. Monetarne rehuliuvannia ekonomiky Ukrainy: potochni vyklyky i zadachi [Text] / S. Arzhevitin // Naukovyi visnyk Uzhhorodskoho universytetu. - 2016. - Vol. 1 No. 1 (47). - P. 319-326.
35. Pro vplyv polityky derzhavnykh zapozychen ta podatkovoi polityky na stan hroshovo-kredytnoi sfery Ukrainy [Electronic resource]: Rishennia Rady Natsionalnoho banku Ukrainy No. 49. October 31, 2017. - Available at: \www/URL: http://zakon5. rada.gov.ua/laws/show/vr049500-17\#n10

36. Pro diialnist Pravlinnia Natsionalnoho banku Ukrainy shchodo vykonannia Osnovnykh zasad hroshovo-kredytnoi polityky v sichni - veresni 2017 roku [Electronic resource]: Rishennia Rady Natsionalnoho banku Ukrainy No. 50. - October 31, 2017. - Available at: \www/URL: http://zakon2.rada.gov.ua/ laws/show/ru/vr050500-17

37. Pro skhvalennia Stratehii reformuvannia systemy upravlinnia derzhavnymy finansamy na 2017-2020 roky [Electronic resource]: Rozporiadzhennia Kabinet Ministriv Ukrainy No. 124. February 8, 2017. - Available at: \www/URL: http://www. kmu.gov.ua/control/uk/cardnpd?docid $=249797370$

\section{ИССЛЕДОВАНИЕ ВЗАИМОДЕЙСТВИЯ ФИСКАЛЬНОЙ И МОНЕТАРНОЙ ПОЛИТИКИ В УСЛОВИЯХ ОБЕСПЕЧЕНКЯ ЗКОНОМКЧЕСКОГО РОСТА УКРАИНЫ}

Проведена оценка взаимодействия денежно-кредитной и бюджетно-налоговой политики. Определены особенности экономического развития Украины. Исследованы факторы формирования государственного долга Украины. Установлено, что в национальной экономике отсутствует позитивный синергетический эффект фискальной и монетарной политики. Предоставлены результаты анализа долговых обязательств государства и денежно-кредитного регулирования. Предложены меры регуляторного воздействия государства на рыночную конъюнктуру.

ключевые слова: монетарная и фискальная политика, факторы и инструменты эффективного взаимодействия, структура и управление долговыми обязательствами государства.

Zavadska Diana, PhD, Associate Professor, Department of Banking, Odessa National Economic University, Ukraine, e-mail: zavadska. diana@ukr.net, ORCID: http://orcid.org/0000-0003-2950-554X

\section{Filippova L., Tushynska V.}

\section{INVESTIGATION OF ADVANTAGES AND DISADVANTAGES OF MARKET ECONOMY}

Проведено аналіз поняття ринкової економіки. Розглянуто позитивні та негативні сторони ринкової економіки, а також правильності трактування даного терміну згідно сучасних тенденцій. Зроблено висновок про те, як правильно, на погляд авторів, потрібно трактувати саме поняття «ринкова економіка». Також проаналізовано зміни стану економіки країн, які перейшли на ринкову економіку, а саме: Естонія, Латвія, Литва.

Ключові слова: ринкова економіка, переваги та недоліки ринкової економіки, валовий внутрішній продукт (ВВП), експорт країн Прибалтики.

\section{Introduction}

The market economic system is the dominant mode of the economic life of the present. Therefore, its research is an actual problem for every industrial enterprise and the economy as a whole. Recently, more attention is paid to the analysis of the market economy, its impact and possible improvements to achieve the greatest positive result. In order to form an effective functioning of the enterprise and the economy as a whole, it is necessary to have a perfect knowledge of the information for making a decision.

\section{The object of research and its technological audit}

The object of research is the formation of a market economy. 